\title{
Molecular detection of Erwinia psidii in guava plants under greenhouse and field conditions
}

\author{
Detecção molecular de Erwinia psidii em goiabeira em \\ condições de casa de vegetação e campo
}

\section{Claudênia Ferreira da Silva ${ }^{I}$ Carlos Hidemi Uesugi ${ }^{I}$ Luiz Eduardo Bassay Blum ${ }^{\mathrm{I}}$ Abi Soares dos Anjos Marques ${ }^{\text {II }}$ Marisa Álvares da Silva Velloso Ferreira ${ }^{{ }^{*}}$}

\section{ABSTRACT}

Erwinia psidii causes bacterial blight of guava (Psidium guajava), an important disease of this crop in Brazil. The pathogen affects branches and twigs of guava trees, reducing yield significantly. Bacterial dissemination often occurs through contaminated but asymptomatic propagating plant material. The objectives of this research were to evaluate the use of BIO-PCR and conventional PCR to detect $\boldsymbol{E}$. psidii in inoculated guava plants grown in a greenhouse and in symptomatic and asymptomatic trees from guava orchards. Erwinia psidii strain IBSBF 1576 was inoculated $\left(10^{7} \mathrm{CFU} \mathrm{mL}^{-1}\right)$ into young guava shoots and plant tissue was analysed at 0, 5, 10, and 15 days after inoculation. Symptoms were observed after 5 days and all inoculated shoots were PCR positive at all times, by both BIO-PCR and conventional PCR Under natural infection conditions, 40 samples were tested by $B I O$ $P C R$ from each of three guava orchards, 20 showing symptoms and 20 asymptomatic. PCR was positive for 58 out of 60 symptomatic samples $(96.7 \%)$ and for $6.7 \%$ of asymptomatic samples, showing that the method can be used to detect the pathogen at early stages of infection. This PCR method may be used as a diagnostic tool to assess bacterial survival, dissemination and disease outbreaks.

Key words: $B I O-P C R$, diagnosis, guava bacterial blight, $P C R$, Psidium guajava.

\section{RESUMO}

Erwinia psidii é o agente causal da seca dos ponteiros da goiabeira (Psidium guajava), uma importante doença dessa cultura no Brasil. O patógeno afeta folhas, frutos, ramos e brotações, reduzindo significativamente a produtividade da cultura. A disseminação do patógeno ocorre por meio de material propagativo contaminado, porém assintomático. Os objetivos do trabalho foram avaliar o uso da BIO-PCR e da PCR convencional para detectar $\boldsymbol{E}$. psidii em plantas inoculadas em casa de vegetação e em plantas sintomáticas e assintomáticas em pomares de goiabeira. A estirpe IBSBF 1576 de $\boldsymbol{E}$. psidii foi inoculada $\left(10^{7} \mathrm{UFC} \mathrm{mL}^{-1}\right)$ em brotações novas de mudas de goiabeira e o tecido foi analisado nos tempos 0, 5, 10, e 15 dias após a inoculação. Sintomas foram observados após 5 dias e todas as plantas inoculadas foram positivas por PCR em todos os tempos avaliados, pelos dois métodos (BIO-PCR e PCR convencional). Sob condições de infecção natural em campo, três pomares foram avaliados por BIO-PCR. De cada pomar, foram coletadas 40 amostras, sendo 20 com e 20 sem sintomas. PCR foi positiva para 58 das 60 amostras sintomáticas (96,7\%) e para 6,7\% das amostras assintomáticas, demonstrando que o método pode ser usado para detectar o patógeno nos estágios iniciais da infecção. Este método poderá ser útil como uma ferramenta para a diagnose e para monitorar a sobrevivência e disseminação da bactéria e, consequentemente, novos focos da doença.

Palavras-chave: $B I O-P C R$, diagnose, seca dos ponteiros, $P C R$, Psidium guajava.

\section{INTRODUCTION}

An important bacterial (Erwinia psidii) disease known as "guava bacterial blight" limits guava (Psidium guajava L.) production in Brazil. Symptoms of this disease are drying of young shoots followed by wilt and blackening; yellowing of leaves, showing water-soaked lesions close to veins as well as black necrosis of flowers and young fruits. It was first described in São Paulo, in 1983 (RODRIGUES NETO et al., 1987) and further reported in Paraná, Espírito Santo, Minas Gerais, Federal District, and

\footnotetext{
IDepartamento de Fitopatologia, Universidade de Brasília (UnB), 79919-970, Brasília, DF, Brasil. E-mail: marisavf@unb.br. ${ }^{*}$ Corresponding author.

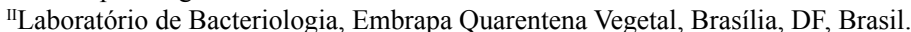


Goiás. In the Federal District central Brazil, high yield losses have been reported (MARQUES et al., 2007). E. psidii also affects Eucalyptus spp. in Brazil (ARRIEL et al., 2014), Argentina and Uruguay (COUTINHO et al., 2011). Symptoms in this host include wilt and dieback.

During sanitary inspections, whether examining plant propagating material or seeds, reliable and efficient methods to detect and identify associated pathogens are necessary. Preventive control measures can be effective when applied at early stages of disease development. Plant disease diagnosis based on symptoms is rarely used as a single method due to its limitations. Molecular techniques are valuable tools in this process and can be employed for simultaneous detection and identification of plant pathogens. These techniques are less time-consuming, highly specific, and there is no need to isolate the pathogen. Additionally, DNA-based techniques are very sensitive (VINCELLI \& TISSERAT, 2008; LÓPEZ et al., 2009). PCR with specific primers is able to detect and identify target DNA in complex mixtures (MUMFORD et al., 2006), and can be employed to detect pathogens in asymptomatic plant material (LLOP et al., 2000).

Dissemination of guava bacterial blight in Brazil occurs probably due to the movement of contaminated plant material. Considering the need for validated methods to detect $\boldsymbol{E}$. psidii in asymptomatic plant material, recently it was designed a specific PCR protocol for $\boldsymbol{E}$. psidii (SILVA et al., 2015). The objective of the present research was to show the application of this method in detecting the pathogen in inoculated guava plants by conventional PCR and BIO-PCR over time, and to validate BIO-PCR as a method suitable for inspection of guava orchards, under natural infection conditions.

\section{MATERIALS AND METHODS}

\section{Bacterial strains and culture conditions}

The strains used in this research were IBSBF 1576 and IBSBF 435 (type strain, CFBP 3627, NCPPB 3555 ). Strains were grown on 523 culture medium (KADO \& HESKETT, 1970) at $29^{\circ} \mathrm{C}$ for 24 hours, maintained in water suspensions at room temperature, and at $-20^{\circ} \mathrm{C}$ in $20 \%$ glycerol (SCHAAD et al., 2001). The strain IBSBF 1576, which has been collected in an orchard located in Brazlândia, DF, in 2001, was chosen because of its high aggressiveness on guava, shown during preliminary assays. Guava plants, cultivar 'Pedro Sato', were inoculated under greenhouse conditions in order to establish an effective protocol to detect $\boldsymbol{E}$. psidii before symptom development. Afterwards the method was applied in a field inspection situation, under natural infection conditions.

Greenhouse conditions: detection by PCR and BIO-PCR The greenhouse experiment was designed entirely at random, with four treatments that consisted of pathogen detection at $0,5,10$ and 15 days after inoculation. Each treatment had four replicates, corresponding to four plants with at least six shoots each. Four plants inoculated with sterile water, one plant per treatment, were used as control. Plants were kept under temperatures ranging from 23 to $30^{\circ} \mathrm{C}$. Inoculation was performed by slightly wounding the axils of the last fully expanded leaves of each shoot, with a hypodermic syringe gauge, followed by depositing a drop of bacterial suspension of strain IBSBF 1576 on the wounds. Suspension was prepared from a $48 \mathrm{~h}$ culture and adjusted to $8 \%$ transmittance in a spectrophotometer followed by a 10 -fold dilution to obtain a suspension at $10^{7} \mathrm{CFU}$ $\mathrm{mL}^{-1}$. Plants were covered with plastic bags to provide high humidity for 72 hours. Samples were collected from inoculated plants, regularly, at $0,5,10$ and 15 days after inoculation, and submitted to conventional PCR and BIO-PCR using $\boldsymbol{E}$. psidii-specific primers, Ep2L (3' CCA AAA AGC TTG GTG TGG ATA 5') and Ep2R (3' AAA TTG GTG ACT CGC ACA TG 5') and the protocols described by SILVA et al. (2015). Plants were daily inspected for symptom development and disease progress.

For BIO-PCR (SCHAAD et al., 1995), shoot samples $(1 \mathrm{~g})$ were crushed in $2 \mathrm{~mL}$ of sterile water using a mortar and pestle. Aliquots of $100 \mu \mathrm{L}$ were transferred to solid 523 culture medium, in triplicate Petri dishes, and incubated at $29^{\circ} \mathrm{C}$ for 24 hours. Small but typical colonies of $\boldsymbol{E}$. psidii can be observed after this period and there are no differences in the amplification results employing 24 or $48 \mathrm{~h}$ of growth (SILVA et al., 2015). Plates were then washed with $2 \mathrm{~mL}$ of distilled sterile water, and $1 \mathrm{~mL}$ of this suspension was diluted to $10^{-1}$. PCR reactions were carried out by using $\boldsymbol{E}$. psidii specific primers Ep2L/ Ep2R, which amplifies a $\sim 200 \mathrm{bp}$ fragment of the rec A gene (SILVA et al., 2015). Amplification reactions were performed in $25 \mu \mathrm{L}$, containing $0.1 \mathrm{mM}$ of dNTPs, PCR reaction buffer $(10 \mathrm{mM}$ Tris $\mathrm{HCl}, 50 \mathrm{mM}$ $\mathrm{KCl}), 1.25 \mathrm{mM} \mathrm{MgCl}, 0.5 \mu \mathrm{M}$ of each primer, $0.5 \mathrm{U}$ of Taq DNA polymerase and $3 \mu \mathrm{L}$ of the diluted plate washings. PCR was performed in an PTC-100 thermocycler (MJ Research, Inc.), programmed for an initial denaturation step of $3 \mathrm{~min}$ at $95^{\circ} \mathrm{C}$, followed 
by 32 cycles of $1 \mathrm{~min}$ at $94^{\circ} \mathrm{C}, 1 \mathrm{~min}$ at $64^{\circ} \mathrm{C}$ and $2 \mathrm{~min}$ at $72^{\circ} \mathrm{C}$, with a final extension of $5 \mathrm{~min}$ at $72^{\circ} \mathrm{C}$. Two negative controls were included in all experiments: $3 \mu \mathrm{L}$ of washes from healthy guava leaf extracts and a water control (reaction free of any DNA). Two positive controls were also included: $3 \mu \mathrm{L}$ of a bacterial suspension of $10^{6} \mathrm{CFU} / \mathrm{mL}$ and a reaction with purified DNA of $\boldsymbol{E}$. psidii type strain (IBSBF $435)$ as template $(30 \eta g)$. PCR products $(10-12 \mu \mathrm{L})$ were detected by electrophoresis on $1 \%$ agarose gels in $0.5 \mathrm{X}$ TBE buffer, followed by staining with ethidium bromide (EtBr $1 \mu \mathrm{g} \mathrm{mL}^{-1}$ ), visualized under UV and photographed using the image system L-PIX (Loccus Biotecnologia, Cotia, SP; Brazil).

For conventional PCR, guava shoot samples were cut into small fragments, macerated in sterile distilled water $(1 \mathrm{~g}$ of plant tissue per $5 \mathrm{~mL}$ of water), placed in $250 \mathrm{~mL}$ - Erlenmeyer flasks, and maintained in an orbital shaker for 1 hour at 200rpm. The resulting extract was centrifuged for $10 \mathrm{~min}$ at 13,200rpm. The supernatant was then discarded and the pellet resuspended in $250 \mu \mathrm{L}$ of the ice-cold buffer from the Pathoscreen ${ }^{\circledR}$ kit (Agdia), containing sodium sulfite, sodium azide, polyvinylpyrrolidone and albumin. PCR reactions were carried out by using the specific primers Ep2L/Ep2R and, as target, $3 \mu \mathrm{L}$ of undiluted plant extracts prepared as described above, as well as two more reactions of each sample, diluted to $10^{-1}$ and $10^{-2}$. Negative and positive controls were also included as previously described. Amplification reactions and program, electrophoresis and gel staining were conducted as described above.

Guava orchards: detection by BIO-PCR

The BIO-PCR protocol under field conditions was validated by collecting samples from 20 symptomatic and 20 asymptomatic guava plants cv. Pedro Sato in three randomly chosen orchards in Brazlândia, DF. Orchards were three, 11 and 13 years old and had a history of guava bacterial blight incidence. In the two older ones, bacterial blight had been present for at least seven years. The symptomatic trees showed wilt and blackening of newly developed shoots. When it was difficult to find healthy trees, apparently healthy leaves and shoots were collected from diseased trees. All samples were stored in a cold chamber at $4^{\circ} \mathrm{C}$ until analyzed by $\mathrm{BIO}-\mathrm{PCR}$, according to the protocol described above.

\section{RESULTS AND DISCUSSION}

In the greenhouse experiment, all samples were PCR positive for the presence of $\boldsymbol{E}$. psidii. The bacterium was detected in plant extracts at all times and by both PCR and BIO-PCR (Table 1; Figure 1A and B). Regarding symptom development, greasing and vein blackening were observed at the fifth day after inoculation, which became highly evident after 10 days (Figure 1C) and led to wilt and shoot necrosis after 15 days. Plants inoculated with water as control developed no symptoms and presented negative results for both detection methods.

Under natural infection conditions, only BIO-PCR was used to detect $\boldsymbol{E}$. psidii in guava orchards. The first orchard was highly affected by the disease, with a large number of trees showing typical symptoms. As a result, $\boldsymbol{E}$. psidii was detected by BIO-PCR in 18 out of 20 symptomatic plants and in three out of 20 asymptomatic ones. In the second orchard, most plants were also affected by the disease, and the PCR result was 20/20 positives from symptomatic material and only one positive out of 20 asymptomatic samples. The third orchard had been established only three years before the sampling but it showed already high incidence of bacterial blight. All 20 symptomatic samples were PCR positive, and, by contrast, none was positive among the asymptomatic plants $(0 / 20)$ (Figure 2A). Whenever a symptomatic sample fail to give a positive amplification, PCR was repeated using plate washings diluted to $10^{-2}$, to verify any inhibition due to excessive bacterial growth. Considering all the samples, the field assay using BIO-PCR resulted in 58/60 (96.7\%) positives for symptomatic samples (Figure 2B) and 4/60 (6.7\%) for the asymptomatic ones.

Our results showed that it is possible to detect $\boldsymbol{E}$. psidii at early stages of infection and before symptom emergence. After the greenhouse

Table 1 - Detection of Erwinia psidii by conventional PCR and BIO-PCR in guava plants under greenhouse conditions, related to time after inoculation and symptom expression.

\begin{tabular}{llcc}
\hline $\begin{array}{l}\text { Days after } \\
\text { inoculation }\end{array}$ & Symptoms & PCR & BIO-PCR \\
\hline 0 & - & $6^{3} / 6^{4}$ & $9 / 9$ \\
5 & $+^{1}$ & $6 / 6$ & $9 / 9$ \\
10 & + & $6 / 6$ & $9 / 9$ \\
15 & $++^{2}$ & $6 / 6$ & $9 / 9$ \\
\hline
\end{tabular}

${ }^{1}$ Greasing and vein blackening; ${ }^{2}$ shoot necrosis symptoms; ${ }^{3}$ Number of PCR positive samples; ${ }^{4}$ Total number of samples from three inoculated plants. Conventional PCR performed in duplicate reactions and $\mathrm{BIO}-\mathrm{PCR}$ in triplicate reactions. 


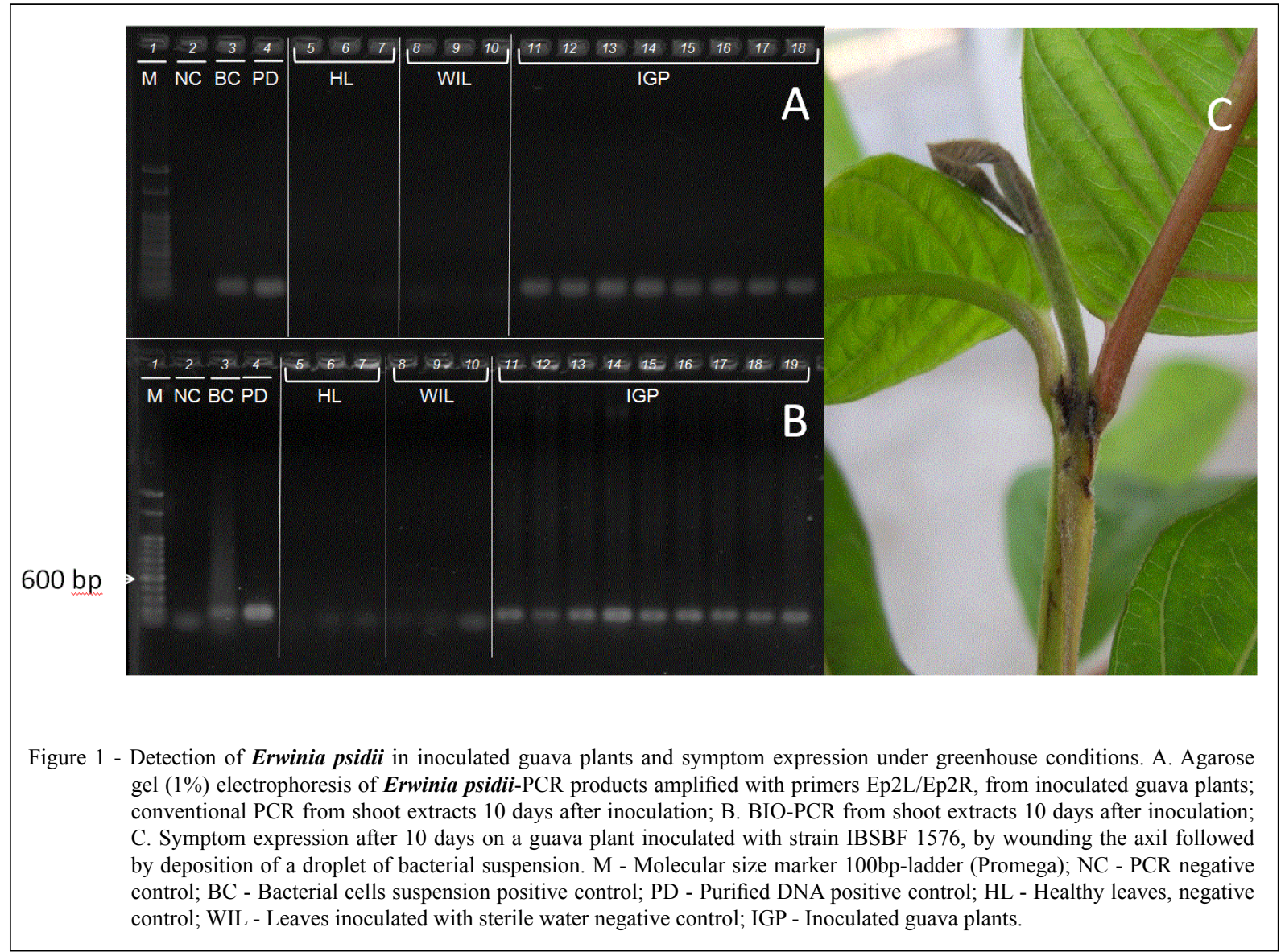

inoculation, samples were collected at time "zero", four to six hours after inoculation. All PCR results were positive, due to the living cells probably dispersed at the point of inoculation on the leaf/ shoot surface. Five days after inoculation, all amplifications were positive and the early greasing symptom could be seen near the inoculation points. At that time, bacterial cells must have already entered the intercellular spaces and started the colonization process. Considering that greasing is the first symptom of bacterial infection (COUTINHO et al., 2011), it is clear that the infection process had been established.

BIO-PCR was a suitable method for detection purposes in guava orchards. It was reported a high correlation between PCR-positive plants and the presence of symptoms, which was $96.7 \%$ of cases. Two out of 60-symptomatic-samples gave negative results. This was probably due to misdiagnosis, when natural discoloration of guava branches is often mistaken as bacterial blight symptoms or leakage due to the distribution of cells over the tissue. MARQUES et al. (2007) reported in $81.9 \%$ of cases a correlation between presence of symptoms and laboratorial diagnosis, by bacterial isolation on culture medium. The correlation reported here between presence of symptoms and BIO-PCR was higher than that observed by those authors.

Four samples out of 60 asymptomatic ones $(6.7 \%)$ resulted in positive bacterial detection by BIO-PCR. Those four apparently healthy shoots probably harbor a bacterial population which was not large enough to induce symptoms (CHOUDHARY \& SCHMIDT-DANNERT, 2010), or that modifies the environment to improve its habitat without causing disease, and at the same time suppressing or evading plant defenses (BEATTIE \& LINDOW, 1999). However, this small population was within the detection limit of our BIO-PCR assay with primers Ep2L/2R which is $10 \mathrm{CFU} \mathrm{ml}{ }^{-1}$ or $20 \mathrm{CFU} \mathrm{g} \mathrm{g}^{-1}$ of leaf tissue according to our previous research (SILVA et al., 2015). The other $93.3 \%$ of the samples were PCR negative but may contain a population below the detection limit of the primers. Considering the 


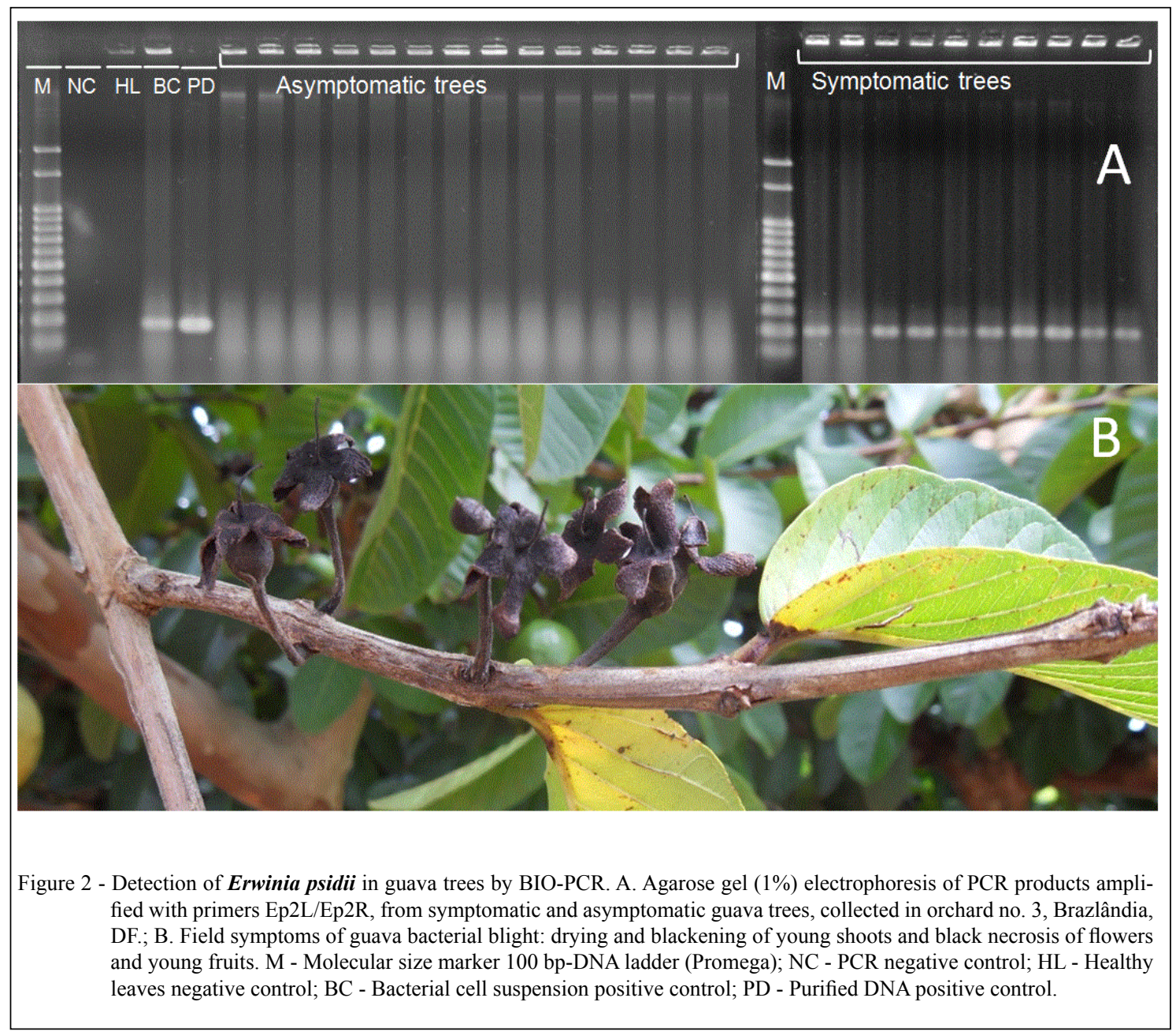

presence of symptomatic plants in the same orchard, the constant monitoring of these asymptomatic plants would be highly recommended for disease management in those areas. For other plant-bacteria interactions, PCR has also proven to be a reliable tool for detection in asymptomatic material. For example, SCHAAD et al. (1999) reported that $18 / 20$ symptomless potato tubers were contaminated by Clavibacter michiganensis subsp. sepedonicus, using BIO-PCR. For samples of symptomless rosaceous plants, LLOP et al. (1999) detected Erwinia amylovora contamination in 62, 42 and 51 out of 251 samples by nested-PCR in a single tube, standard one-round PCR and two-tube nestedPCR, respectively. Such methods can detect low levels of bacterial contamination, thus ensuring that only propagating material that is free of bacterial contamination is moved from place to place.

A very important step in BIO-PCR is the dilution of plate washings to prevent false negatives as shown by SCHAAD et al. (1999) for $\boldsymbol{C}$. michiganensis subsp. sepedonicus. Plate washings from undiluted potato samples failed to amplify, while from diluted ones amplification was positive as expected. In our study, plate washings were diluted to $10^{-2}$, resulting in positive amplification for all symptomatic samples. False negatives can be due to the presence of inhibitors or excess of target DNA, in this case using PCR internal controls should be highly desirable, as described by MIDORIKAWA et al. (2008), to ensure the test's reliability.

Despite the promising results of BIO-PCR for $\boldsymbol{E}$. psidii detection, more sensitive methods such as real-time PCR must still be considered to prevent false negatives from asymptomatic propagating material (WELLER et al., 2006; PELOSI et al., 2013; SIKDAR et al., 2014). Another possibility is the use of nested-PCR (LLOP et al., 1999; LÓPEZ et al., 2009), although it might be limited by the length of the Ep2L/Ep2R amplified product. Recently, a loop- 
mediated isothermal amplification (LAMP) has been describe for improving diagnosis and detection of $\boldsymbol{E}$. amylovora (BÜHLMANN et al., 2013), and may be an alternative for $\boldsymbol{E}$. psidii.

\section{CONCLUSION}

The PCR method used in this research could be very useful as a tool in a multiphasic approach for diagnosis of bacterial blight. Together with conventional diagnostic tests, this method could also be applied in epidemiological studies of the survival of $\boldsymbol{E}$. psidii in crop debris, in soil, on alternative hosts and insects, and pathogen translocation in guava plants.

\section{ACKNOWLEDGEMENTS}

C. F. Silva was supported by Coordenação de Aperfeiçoamento de Pessoal de Nível Superior (CAPES). We are grateful to Dr. Júlio Rodrigues Neto, curator of Coleção de Culturas de Fitobactérias do Instituto Biológico's (IBSBF), Campinas, SP, for kindly providing the strains, to Kenshiro Tsusumi, Bruno Tsusumi and Takimi Tsusumi, owners of the studied guava orchards, and Joanice P.S. Damasceno, José Cezar Castro, and Arenildo Soares for their technical assistance. This research was funded by Fundação de Amparo à Pesquisa do Distrito Federal (FAP-DF), grant 193.000.254/2007.

\section{REFERENCES}

ARRIEL, D.A.A. et al. Wilt and die-back of Eucalyptus spp. caused by Erwinia psidii in Brazil. Forest Pathology, v.44, n.4, p.255-265, 2014. Available from: <http://onlinelibrary.wiley. com/doi/10.1111/efp.12087/epdf>. Accessed: Nov. 3, 2014. doi:10.1111/efp.12087.

BEATTIE, G.A.; LINDOW, S.E. Bacterial colonization of leaves: a spectrum of strategies. Phytopathology, v.89, n.5, p.353359, 1999. Available from: <http://apsjournals.apsnet.org/doi/ pdf/10.1094/PHYTO.1999.89.5.353>. Accessed: Nov. 4, 2014 doi: 10.1094/PHYTO.1999.89.5.353.

BÜHLMANN, A. et al. Erwinia amylovora loop-mediated isothermal amplification (LAMP) assay for rapid pathogen detection and on-site diagnosis of fire blight. Journal of Microbiological Methods, v.92, n.3, p.332-339, 2013. Available from: <http:// www.sciencedirect.com/science/article/pii/S0167701212004149>. Accessed: Nov. 4, 2014. doi: 10.1016/j.mimet.2012.12.017.

CHOUDHARY, S.; SCHMIDT-DANNERT, C. Applications of quorum sensing in biotechnology. Applied Microbiology and Biotechnology, v.86, n.5, p.1267-1270, 2010. Available from $<$ http://download.springer.com/static/pdf/531>. Accessed: Nov. 5, 2014. doi: 10.1007/s00253-010-2521-7.

COUTINHO, T.A. et al. A new shoot and stem disease of Eucalyptus species caused by Erwinia psidii. Australasian Plant Pathology, v.40, n.1, p.55-60, 2011. Available from: <http:// download.springer.com/static/pdf/32>. Accessed: Nov. 6, 2014 doi 10.1007/s13313-010-0013-y.
KADO C.E.; HESKETT M.G. Selective media for isolation of Agrobacterium, Corynebacterium, Erwinia, Pseudomonas and Xanthomonas. Phytopathology, v.60, p.969-976, 1970. Available from: $<$ https://www.apsnet.org/publications/phytopathology/backissues/ Documents/1970Articles/Phyto60n06_969.PDF>. Accessed: Nov. $6,2014$.

LLOP, P. et al. Development of a highly sensitive nested-PCR procedure using a single closed tube for detection of Erwinia amylovora in asymptomatic plant material. Applied and Environmental Microbiology, v.66, n.5, p.2071-2078, 2000. Available from: <http://www.ncbi.nlm.nih.gov/pmc/articles/ PMC101457/pdf/am002071.pdf >. Accessed: Nov. 6, 2014.doi 0099-2240/00/\$04.0010.

LÓPEZ, M.M. et al. Are molecular tools solving the challenges posed by detection of plant pathogenic bacteria and viruses? Current Issues in Molecular Biology, v.11, p.13-46, 2009. Available from: <http://www.horizonpress.com/cimb/v/v11/13. pdf>. Accessed: Nov. 6, 2014.

MARQUES, A.S.A. et al. Seca dos ponteiros da goiabeira causada por Erwinia psidii: níveis de incidência e aspectos epidemiológicos. Revista Brasileira de Fruticultura, v.29, n.3, p.488-493, 2007. Available from: <http://www.scielo.br/pdf/ rbf/v29n3/a16v29n3.pdf>. Accessed: Nov. 5, 2014. doi 10.1590/ S0100-29452007000300016

MIDORIKAWA, G.E.O. et al. Characterization of Aspergillus flavus strains from Brazilian Brazilnuts and cashew by RAPD and ribosomal DNA analysis. Letters in Applied Microbiology, v.47, n.1, p.12-18, 2008. Available from: $\quad<$ http://onlinelibrary.wiley.com/doi/10.1111/j.1472765X.2008.02377.x/epdf $>$. Accessed: Nov. 5, 2014. doi: 10.1111/j.1472-765X.2008.02377.x.

MUMFORD, R. et al. Advances in molecular phytodiagnostics - new solutions for old problems. European Journal of Plant Pathology, v.116, n.1, p.1-19, 2006. Available from: <http:// download.springer.com/static/pdf/895>. Accessed: Nov. 1, 2014. doi 10.1007/s10658-006-9037-0

PELOSI, C.S. et al. Development of a Taqman real-time PCR assay for detection of Leifsonia xyli subsp. xyli. Tropical Plant Pathology, v.38, n.4, p.343-345, 2013. Available from: <http:// www.scielo.br/pdf/tpp/v38n4/tpp533.pdf>. Accessed: Nov. 1, 2014. doi: $10.1590 / \mathrm{S} 1982-56762013005000013$.

RODRIGUES NETO, J. et al. A bacterial disease of guava (Psidium guajava) caused by Erwinia psidii sp. nov. Fitopatologia Brasileira, v.12, n.4, p.345-350, 1987.

SCHAAD, N.W. et al. Detection of Clavibacter michiganensis subsp. sepedonicus in potato tubers by an automated real-time fluorescence detection system. Plant Disease, v.83, n.12, p.10951100, 1999. Available from: <http://apsjournals.apsnet.org/doi/ pdf/10.1094/PDIS.1999.83.12.1095>. Accessed: Nov. 3, 2014. doi: 10.1094/PDIS.1999.83.12.1095

SCHAAD, N.W. et al. A combined biological and enzymatic amplification (BIO-PCR) technique to detect Pseudomonas syringae pv. phaseolicola in bean seed extracts. Phytopathology, v.85, n.2, p.243-248, 1995. Available from: $<$ https://www.apsnet.org/publications/phytopathology/ backissues/Documents/1995Articles/Phyto85n02_243.pdf>. Accessed: Nov. 3, 2014 
SCHAAD, N.W. et al. Laboratory guide for identification of plant pathogenic bacteria. 3.ed. Minnesota: APS, 2001. 373p.

SIKDAR, P. et al. Development of PCR assays for diagnosis and detection of the pathogens Phacidiopycnis washingtonensis and Sphaeropsis pyriputrescens in apple fruit. Plant Disease, v.98, n.2, p.214-246, 2014. Available from: <http:// apsjournals.apsnet.org/doi/pdf/10.1094/PDIS-05-13-0495-RE>. Accessed: Dec. 3, 2014. doi: 10.1094/PDIS-05-13-0495-RE.

SILVA, C.F. et al. PCR-based methods for detection of Erwinia psidii on guava. Tropical Plant Pathology, v.40, n.4, p.251-259, 2015. Available from: <http://link.springer.com/article/10.1007
\%2Fs40858-015-0020>. Accessed: Jul. 12, 2015 . doi 10.1007/ s40858-015-0020-1.

VINCELLI, P.; TISSERAT, N. Nucleic acid-based pathogen detection in applied plant pathology. Plant Disease, v.92, n.5, p.660-669, 2008. Available from: <http://apsjournals.apsnet.org/ doi/pdf/10.1094/PDIS-92-5-0660>. Accessed: Jun. 10, 2015doi: 10.1094/PDIS-92-5-0660.

WELLER, A.S. et al. Molecular diagnosis of plant pathogenic bacteria. Arabian Journal of Plant Protection, v.24, n.2, p.143146, 2006. Available from: <http://www.asplantprotection.org/ PDF/AJPP/24-2_2006/143-146.pdf>. Accessed: Jun. 20, 2015. 